\title{
WAW ATHAF DALAM AL-QUR'AN (Analisis Makna dan Fungsi)
}

\author{
Asriyah \\ Email: asriyah-diwan@gmail.com \\ Universitas Islam Negeri (UIN) Alauddin Makassar
}

\begin{abstract}
Abstrak
Permasalahan utama adalah "bagaimana makna dan fungsi waw 'aţhaf dalam al-Qur'an. Dari masalah pokok ini diperlukan penjabaran dalam bentuk sub-sub masalah sebagai berikut: 1) bagaimana pengertian waw 'athaf dan pembagiannya, 2) bagaimana fungsi dan makna waw 'athaf dalam al-Qur'an. Dengan demikian, penilitian ini bertujuan untuk mengungkapkan dan menganalisis fungsi dan makna waw 'athaf dalam al-Qur'an. Guna menjawab permasalahan di atas dipergunakan pendekatan ilmu bahasa yang komprehensif dengan teknik interpretasi linguistik, interpretasi sosio-historis, dan interpretasi logis, dan interpretasi ganda. Sesuai permasalahan di atas, maka yang menjadi objek penelitian adalah waw 'athaf dalam al-Qur'an. Gagasan-gagasan yang terkandung dalam fungsi dan makna waw ataf ditelaah secara analisis sitematis, kemudian disusun sebuah konsep yang berkenaan dengan objek kajian. Objek-objek yang dapat diinterpretasi dari ayat-ayat Al-Qur'an tersebut selain huruf waw 'athaf, juga kosa kata, frasa, klausa, dan ayat-ayat AlQur'an itu sendiri. Ini berarti bahwa ketika menghadapi sebuah ayat Al-Qur'an, peneliti menganalisis ayat itu pada bagian penggunaan waw 'athaf dan ayat itu dalam bagian-bagian kecil di atas. Hasil penelitian yang diperoleh bahwa pada beberapa ayat dari al-Qur'an bahwa fungsi dan makna waw sebagai alat athaf sebagai alat penggabung murni dan penggabungan secara berurutan. penggabungan secara berurutan mengandung dua kemungkinan yaitu urutan waktu dan urutan prioritas. Hal ini tentu memberikan dampak yang cukup signifikan terhadap penafsiran.

Kata Kunci: Waw athaf, makna dan fungsi.
\end{abstract}

\section{A. Pendahuluan}

Al-Qur'an al-Karīm adalah kitab yang oleh Rasul saw. dinyatakan sebagai ma'dubah Allah sebagaimana dikutip M. Quraish Shihab. Hidangan ini membantu manusia untuk memperdalam pemahaman dan penghayatan tentang Islam dan merupakan pelita bagi umat Islam dalam menghadapi berbagai persoalan hidup. ${ }^{1}$

Agar Al-Qur'an benar-benar dapat dijadikan petunjuk dan pedoman, maka ia harus dibaca, dimengerti dan dipahami kandungannya. Untuk tujuan itu, 
diperlukan penafsiran terhadap ayat-ayatnya. Tujuan tersebut telah dilakukan oleh Nabi saw. sehingga kedudukannya sebagai the first interpreter atau al-mufassìr alawwal, telah menjelaskan kandungan Al-Qur'an kepada umatnya. Hal ini dapat dimengerti, sebab Nabi saw. telah mendapatkan garansi dari Allah swt. dalam menafsirkan Al-Qur'an. ${ }^{2}$

Salah satu syarat dasar menafsirkan Al-Qur'an adalah menguasai bahasa Arab, sebab itulah bahasa Al-Qur'an sebagaimana dalam QS. Yūsuf/12: 2, yakni:

Terjemahnya :

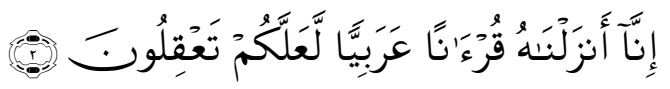

Sesungguhnya Kami menurunkannya berupa Al-Qur'an berbahasa Arab, agar kamu mengerti. ${ }^{3}$

Demikian pula dalam QS. Al-Qamar/54: 17 disebutkan bahwa,

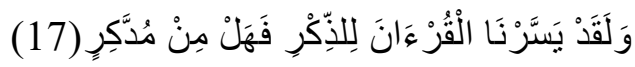

Terjemahnya:

Dan, sungguh telah Kami mudahkan Al-Qur'an untuk peringatan, maka adakah orang yang mau mengambil pelajaran. ${ }^{4}$

Muhammad Mahmud Hijāzī dalam mengomentari ayat di atas menyatakan bahwa, sungguh Allah swt. telah permudah al-Qur'an dan dimudahkan bagi orang yang mau mempelajari, membaca, menghafal dan memahaminya. Salah satu bentuk kemudahan itu adalah diturunkannya Al-Qur'an dalam bahasa Arab. ${ }^{5}$ Dalam pada itu, untuk memudahkan mendalami Al-Qur'an, ada tujuh komponen disiplin ilmu bahasa Arab yang harus dikuasai yakni 'ilmu nahw, 'ilmu tashrïf, 'ilmu isytiqāq, 'ilmu bayān, 'ilmu bad̄', 'ilmu qirā'ah, dan 'ilmu ma 'ānī. ${ }^{6}$ Ketujuh disiplin ilmu itu berkaitan dengan huruf dan kata dalam struktur kalimat bahasa Arab, baik dari segi penyebutan, harakat, kedudukannya, maupun makna yang terkandung di dalamnya.

Seperti lazimnya bahasa yang sempurna, bahasa Arab dipastikan mempunyai aturan dan sistem gramatika yang obyek kajiannya secara krusial tertuju kepada kata. Setiap kata dalam kalimat atau bahasa Arab memiliki pososi yang disebut mahallu, salah satu posisi yang dibahas pada uraian ini adalah al'athf. Al-'athaf atau 'athaf merupakan salah satu istilah di dalam gramatika bahasa Arab. Bentuk penggunaan 'athaf, ada yang disebut 'athf al-nasaq dan 'athf al-bayān. 'Athf al-nasaq berfungsi untuk memperjelas kedudukan dan bacaan kalimat dengan diperantarai oleh salah satu alat 'athaf, sedangkan 'athf al-bayān berfungsi untuk memperjelas maksud kalimat tanpa ada alat 'athaf. Penggunaan waw sebagai alat 'athaf termasuk pada bentuk 'athf al-nasaq. Kedua bentuk 'Athaf ini termuat pada banyak ayat Al-Qur'an.

Salah satu persoalan krusial dalam pembahasan 'ataf adalah penentuan ma'thuf 'alihi, jika salah dalam menentukannya akan menimbulkan kekacauan dalam pemkanaan kalimat atau bahasa. Dalam salah satu riwayat dikatakan bahwa, pernah suatu ketika salah seorang membaca Q.S. al-Taubah [9]: 3:

ورسوله sebagai 'athaf dari . Setelah mendengar bacaan tersebut, Abu al-Aswad kaget disertai perasaan khawatir akan terjadinya kekeliruan dalam bacaan al-Qur'an pada masa-masa 
selanjutnya. Apalagi hubungan eksternal umat Islam semakin haru semakin meningkat dengan meluasnya wilayah kekuasaan Islam. ${ }^{1}$

\section{B. Pengertian Athaf dan Pembagiannya}

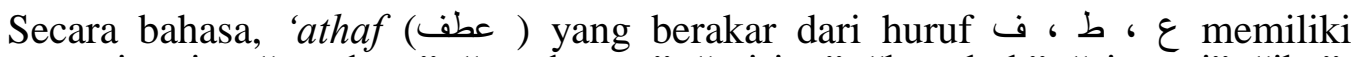
beberapa arti, yaitu: "condong", "cenderung", "miring”, "bengkok", "simpati”, "iba", dan "ketiak". 7 Arti-arti itu sangat bergantung pada huruf jar, idiom yang mengikut kepada kata athaf. Huruf jar "عن" misalnya, akan membawa kata 'athaf bermakna "berpaling" dan atau "menghindar". Sementara huruf jar "على" akan mengantarkannya bermakna: "menaruh simpati", dan "iba", serta "cenderung". Sedangkan huruf jar "ب" menjadikannya bermakna "penyayang"8

Sedangkan secara istilah gramatikal, 'athaf adalah penggabungan antara ma thu $f$ (yang diikutkan) dan ma'thüf 'alaih (yang diikuti) sehingga antara keduanya tunduk dalam satu hukum $i$ 'rāb yang sama. ${ }^{9}$ Pada istilah ini, idiom yang mengikutinya adalah "على عليه" sehingga berbunyi".

Penggabungan antara ma'thuf dan ma'thuf 'alaih dilakukan dengan dua cara. Penggabungan langsung dan penggabungan dengan alat perantara. Penggabungan langsung disebut athaf al-bayan sedangkan penggabungan dengan perantara disebut athaf al-nasaq.

\section{A. Athaf al-Bayān}

Al-Syekh Mustafā Al-Galāyainī mendefinisikan ataf al-bayān sebagai berikut: عطف البيان : هو تابع جامد يشبه النعت فى كونه يكثن عن المر اد كما يكثف النعت 10.

'Athaf al-bayān adalah sesuatu yang mengikut yang berbentuk 'jamid dan menyerupai na'at dalam hal memperjelas maksud.

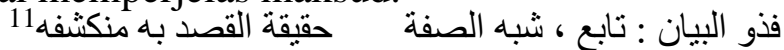

('athaf) bayan: sesuatu yang mengikut serupa dengan sifah dengan maksud memberikan penjelasan.

Frase "bukan kata sifat" pada definisi di atas bertujuan untuk menghindari kesamaan dengan na'at atau sifah. Sebab, na'at juga bertujuan untuk memperjelas maksud "yang diikutinya", namun ia terbentuk dari kata șifah, yang merupakan perubahan dari kata dasarnya.

Frase "tidak bisa dipisahkan antara "yang mengikut" dan "yang diikuti", bertujuan untuk menghindarkan $b a d l^{12}$. Dalam perakteknya, badl dapat berdiri sendiri tanpa mengikut ke matbū'nya.

Penggabungan dengan 'athaf al-bayān dimaksudkan untuk menjelaskan kata sebelumnya yang masih samar apabila matbū'nya ma'rifah; dan bersifat pengkhusus apabila ma 'thufnya nakirah. Karena itu, mirip dengan al-na'at.

Oleh karena serupa dengan na'at dalam hal memperjelas maksud "yang diikutinya", maka 'aţhf al-bayān mengikuti syarat na'at, yaitu: sama $i$ 'rāb, ma 'rifah, nakirah, mużakkar, muannaś, mufrad, muśannā, dan jama'nya antara "yang mengikut" dan "yang diikuti". Contoh 'atf al-bayān dalam kalimat sempurna adalah: "جاء صاحبك" " Kalimat pokok pada contoh ini adalah". Namun, maksud dari kata "صاحبك" belum jelas sehingga untuk memperjelasnya dipandang perlu mengikutkankan kata "محمد" Kata " محمد" pada kalimat ini adalah "atf al-

${ }^{1}$ M. Syukur Derry, "Mughny al-Labib; Telaah terhadap Kaidah Linguistik Ibn Hisyam", Jurnal Adabiyah Vol. XIV Nomor 2/2014, h. 109. 
bayān". Karena "yang diikuti" adalah ma 'rifah, maka "yang mengikut" berfungsi sebagai penjelas.

Dari segi hukum i'rāb, kata "محمد" mengikuti hukum i'rāb lafadz "صاحبك", yaitu marfu' karena fa 'il (pelaku/subyek). Kata "صاحبك" adalah ma 'rifah, mużakkar dan mufrad, maka kata "محد" juga demikan.

Susunan seperti ini banyak ditemukan dalam Al-Qur'an, di antaranya pada Q.S. al-Nūr/24: 35.

Terjemahnya:

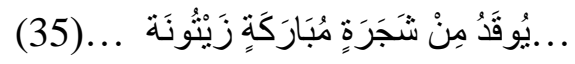

... yang dinyalakan dengan minyak dari pohon yang diberkahi, (yaitu) pohon zaitun. ${ }^{13}$

Kalimat intinya adalah من شجرة مباركة "dinyalakan api dari kayu yang diberkahi", namun belum jelas maksud "kayu yang diberkahi" sebelum disebutkan kata "'زيتونة" yang berkedudukan sebagai 'ataf al-bayan. Karena, "yang diikuti” adalah nakirah, maka "yang mengikut" berfungsi untuk pengkuhususan. Kata "شجرة مباركة" adalah nakirah, muannaś, dan mufrad, maka kata "زينون" juga demikan.

B. 'Athaf Al-Nasaq

Al-Syekh Mustāfā al-Galāyainī mendefinisikan 'ataf al-nasaq sebagai berikut:

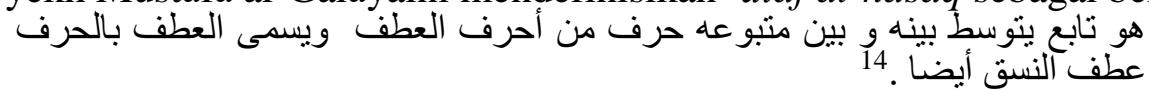

'Ataf al-nasaq adalah sesuatu yang mengikut kepada matbū'nya dengan

diperantarai oleh salah satu harf ataf. ataf nasaq juga disebut ataf dengan huruf

Sejalan dengan itu, 'Imād Hātim memberikan definisi tentang 'ataf al-nasaq sebagai berikut :

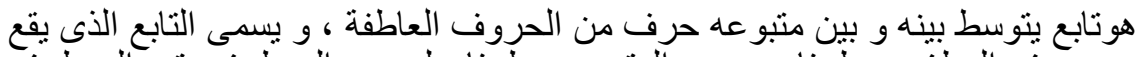

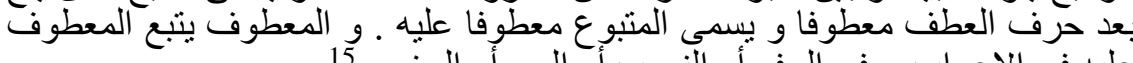

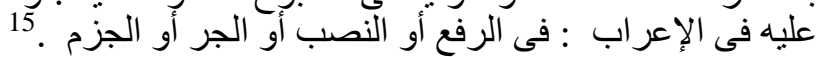

'Ataf al-nasaq adalah sesuatu yang mengikut dan antara yang mengikut dan yang diikuti diantarai oleh salah satu huruf athaf. Yang mengikut yang terletak setelah huruf athaf disebut ma'thüf, sedangkan yang diikuti disebut ma'thüf

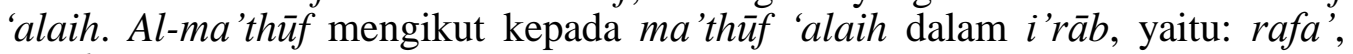
nasab, jar ataupun jazam.

Ibnu Mālik (600-672 H) dalam alfiyahnya mendefinisikan 'athaf al-nasaq dalam bentuk bait syair, sebagai berikut:

$$
\text { نال بحرف متبع عطف النسق كاخصص بود و ثناء من صدق } 16
$$

'Athf al-nasaq adalah sesuatu yang mengikut dan terletak setelah salah satu huruf ( 'aţhf)."

Kata "bi harf" pada definisi Ibnu Malik tersebut membedakan 'athaf al-bayān dengan tawābi ' lainnya.

Berangkat dari beberapa definisi tersebut, diketahui bahwa 'athf nasaq merupakan bentuk penggabungan dalam tata bahasa Arab yang terdiri dari tiga unsur, yaitu: (1) ma'thuf, (2) ma'thuf'alaih, dan (3) harf athaf. Penggabungan yang dimaksudkan tertuju pada ma'thī $f$ dan $m a$ 'thuf'alaih dengan diantarai oleh salah satu huruf athaf. Dengan cara seperti itu, ma'thuf secara otomatis mengikuti ma'thuf 'alaih dalam hukum i'rāb: rafa', nasab, jar ataupun jazam, dan ataupun isi kalimat.

'Athf al-nasaq juga sering disebut 'athf bi al-harf. Hal itu dikarenakan athaf ini menggunakan huruf sebagai alat penggabungnya.

Adapun tujuan dari 'athf al-nasaq ada dua. Penggabungan mutlak dan penggabungan dalam hal lafaz saja. Penggabungan mutlak, artinya penggabungan 
dalam hal hukum i'rāb dan nisbah al-hukm. Contoh pada kalimat biasa, yaitu: "جاء "telah datang Sa‘īd dan Zaid. Kata Sa‘īd digabungkan dengan kata Zaid dengan menggunakan huruf waw, sehingga dengan itu hukum i'rāb kata Zaid mengikuti hukum i'rāb kata Sa'īd, yaitu rafa' karena fā 'il (pelaku/subyek). Sa'īd adalah ma'htuf'alaih; sedangkan Zaid adalah ma'tuf, sementara huruf atafnya adalah waw.

Contoh pada firman Allah adalah Q.S. al-Sajadah/32: 4:

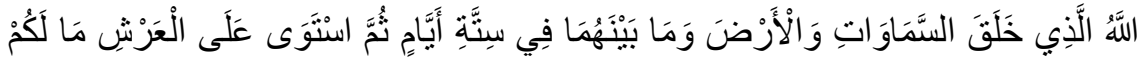

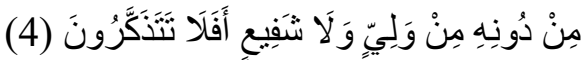

Terjemahnya:

Allah lah yang menciptakan langit dan bumi serta apa yang ada di antara keduanya dalam enam masa, kemudian Dia bersemayam di atas 'Arsy. Tidak ada bagi kamu selain dari pada-Nya seorang penolongpun dan tidak (pula) seorang pemberi syafa'at. Maka, apakah kamu tidak memperhatikan? ${ }^{17}$

Kata الأرض pada ayat tersebut di atas digabungkan dengan kata السموات dengan menggunakan huruf waw, sehingga hukum i'rāb kata الأرض mengikuti hukum $i$ 'rāb kata السموات. Dengan demikian, hukum i 'rāb kedua kata itu sama, yaitu: nashab karena maf' $\bar{u} l$ bih (obyek langsung).

Penggabungan, baik pada contoh kalimat biasa maupun ayat 4 Q.S. alSajadah/32. tersebut, menujukkan penggabungan dalam hal lafaz dan hukum (isi kalimat). Artinya, antara "yang mengikut" dan "yang diikuti" bergabung/sama dalam hukum $i$ 'rāb.

\section{Huruf Athaf Makna dan Fungsinya}

A. Huruf yang berfungsi sebagai Penggabung

Huruf yang Berfungsi dan Bermakna sebagai Penggabung dan Menunjukkan urutan waktu antara ma'thuf dan ma'thuf 'alaih yaitu: waw, fa, dan summa. ${ }^{18}$

a. g/waw bermakna dan berfungsi menggabungkan ma'thuf dan ma'thuf 'alaih dalam hal waktu dan hukum. Contoh: إذا جاء نصر الله و الفتح /apabila telah datang pertolongan Allah dan kemenangan. ${ }^{19}$ Kata الفتح digabungkan dengan kata نصر الله dengan menggunakan huruf áthaf waw, sehingga dengan itu, hukum i'rāb kata الفتح mengikuti hukum i'rāb kata نصر الله , yaitu: rafa' karena fa 'íl (pelaku/subyek).

Selain itu, waktu terjadinya pertolongan Allah bersamaan dengan waktu terjadinya kemenangan. Hal itu dipahami dari digabungkannya kedua kata itu dengan waw áthaf yang menunjukan penggabungan waktu dan hukum.

b. $\quad \dot{d} / \mathrm{f}^{20}$ bermakna dan berfungsi untuk menggabungkan ma'thuf dan ma'thuf álaih dengan menertibkan waktu terjadinya perbuatan dengan selang waktu yang tidak terlalu lama. Contoh: دخل الأستاذ فالطالب/telah masuk guru lalu menyusul murid. Kata الطالب diátafkan kepada kata الأستاذ dengan huruf áthaf fa ( ف ). Ma'thuf dan ma'thuf álaih digabungkan dalam satu hukum yang dikaitkan dengan kata دخل/telah masuk, dan waktu terjadinya berlangsung secara tertib dengan tidak berselang waktu terlalu lama. 
Contoh dalam ayat Al-Qur'an adalah firman Allah swt. pada QS. AlBaqarah/2: 22., sebagai berikut:

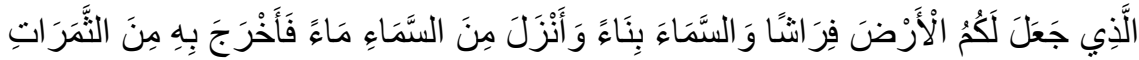

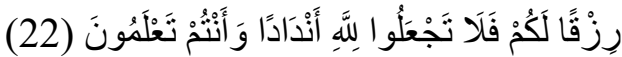

Terjemahnya:

Dialah yang menjadikan bumi sebagai hamparan bagimu dan langit sebagai atap, dan Dia menurunkan air (hujan) dari langit, lalu Dia menghasilkan dengan hujan itu segala buah-buahan sebagai rezki untukmu; karena itu janganlah kamu mengadakan sekutu-sekutu bagi Allah, padahal kamu mengetahui.

Kata أخرج/mengeluarkan athaf kepada kata أنزل /menurunkan dengan perantaraan huruf $f a(\dot{\theta})$. Dari sini dipahami bahwa waktu terjadinya أخرج/mengeluarkan lebih dahulu dari waktu terjadinya أنزل/menurunkan dengan selang waktu tidak terlalu lama.

Penggunaan huruf "ف" sebagai 'adah al- 'atf dengan bentuk ketersusunan terbagi kepada tiga makna. Pertama, ketersusunan lafaz dan penyebutan, kedua, ketersusunan berurutan, dan ketiga, ketersusunan sebab. ${ }^{2}$

Contoh kalimat sempurna dan ayat tersebut di atas untuk makna pertama.

c. ث/Śumma bermakna dan berfungsi untuk menggabungkan ma'thufdan ma'thuf álaih dengan menertibkan waktu terjadinya perbuatan dengan selang waktu agak lama dan atau lama. Dalam bahasa Indonesia, kata ini diterjemahkan "kemudian". Kalimat, إخر المحاضر ثم الطلاب/telah hadir dosen itu, kemudian para mahasiswa adalah salah satu contohnya.

B. Huruf yang Berfungsi dan Bermakna untuk menyatakan bahwa ma'thuf merupakan sebagian dan pembatasan dari ma'thuf 'alaih yaitu ( للغاية/حتى),

Huruf ini dalam bahasa Indonesia diterjemahkan "hingga atau termasuk". Contoh: فر العدو حتى القائد /Musuh itu lari termasuk panglimanya.

Kata القائد/musuh dengan huruf áthaf حتى /العدو/manglima, 'athaf kepada kata, sehingga ma'thüf dan ma'thüf álaih digabungkan ke dalam satu hukum yang dikaitkan kepada makna kata "فر". Karena itu pula dipahami bahwa ma thüf bagian dari ma'thüf álaih. Atau, ma'thūf masuk dalam cakupan ma'thüf álaih, sebab panglima juga termasuk musuh.

" memiliki 4 fungsi, yaitu: 1) sebagai 'adat jar, 2) 'adat nasāb, 3) huruf ibtidāìy, dan 4) 'adat 'athaf. Untuk fungsi 'athaf, ma'thüfnya harus bahagian dari

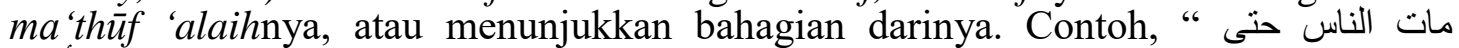
الأنياء/semua manusia akan mati termasuk para Nabi”. Nabi merupakan bahagian dari manusia.

Fungsi "حتى" sebagai 'adat 'athaf bisa untuk antar kata, atau pun antar kalimat sempurna. Sementara di dalam struktur tata bahasa Arab, ia tidak memiliki posisi, yang dalam bahasa i'rāb "لامحل لها من الإعراب". Pola lafaznya tetap dengan harakat sukün pada huruf terakhirnya. ${ }^{23}$

C. Huruf yang Berfungsi dan Bermakna untuk Menentukan Salah Satu Pilihan dan Penegasan yaitu: أو للتخيير / ام ام

Pada penggunaan huruf ini sebagai 'adāt 'ataf, maka ma'tūf álaihnya adalah yang terdekat. Huruf ini dalam bahasa Indonesia diterjemahkan "atau". Contoh: أين /قلمك ؟ هذا أو ذلك 
Kata ذلك 'ataf kepada kata هذا ذأو dengan huruf 'athaf, sehingga dengan itu $m a$ 'thüf dan ma'thüf 'alaih digabungkan dalam satu hukum yang dikaitkan dengan kata قلمك . Pemahaman yang muncul dari kalimat ini adalah bahwa lawan bicara akan memberikan pilihan dan penegasan antara ma'thüf atau ma'thüf álaih.

Sebagai "adat 'athaf, "وأو" memiliki 5 makna, yaitu:

a. "التخيير/pilihan”, contoh: كل تفاحة أو برنقالة/(silahkan pilih mau) makan apel atau jeruk!. Kalimat ini mengandung perintah untuk memilih antara dua kemungkinan, jeruk atau apel.

b. “(kamu boleh) duduk bersama al-Hasan atau al-Husain. Kalimat ini menunjukkan pembolehan bagi subyek kalimatnya melakukan pekerjaan yang berkaitan antara al-Hasan atau alHusain.

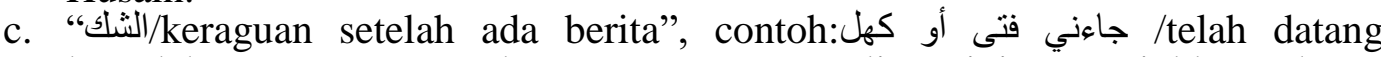
kepadaku, seorang pemuda atau orang tua. Kalimat ini menunjukkan adanya keraguan mengenai orang yang datang, apakah seorang pemuda atau orang tua.

d. "الإبهام/Resamaran di dalam berita", contoh: اعلي سافر أو سعيد/Ali yang berangkat atau $\mathrm{Sa}^{\prime} \overline{1} \mathrm{~d}$. Kalimat ini mengandung kesamaran soal orang yang berangkat, sebab bisa jadi yang berangkat Ali atau Sa'īd.

e. "التفصيل/perincian”, contoh: 2حسن ذاهب أو علي آت24/Hasan pergi atau Ali datang. Kalimat ini bertujuan memberikan perincian terhadap dua berita yang terjadi. Yaitu, Hasan pergi atau Ali datang.

Huruf waw pada "وأو/kata tanya", contoh pada Q.S. al-Syu’ārā/26: 197.

Terjemahnya:

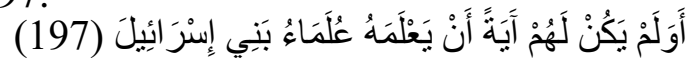

Dan, apakah tidak cukup menjadi bukti bagi mereka, bahwa para ulama Bani Israil mengetahuinya? ${ }^{25}$

"إإما" "إلخيير“" pada dasarnya sama dalam hal menunjukkan pilihan"

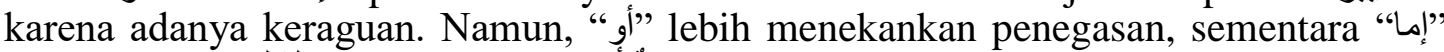

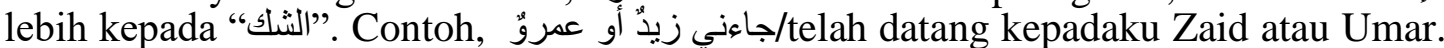
Pada kalimat ini, berita soal "/datang" jatuh kepada Zaid hingga disebutkan kata "أو/auw", lalu muncul keraguan. Keraguan itu pun hanya jatuh kepada 'Umar.

D. Huruf yang Berfungsi Membenarkan Kekeliruan untuk membenarkan kekeliruan dan untuk menyatakan susulan, yaitu: bal (بل/لإول) 26.

$M a$ 'thüf merupakan pernyataan susulan untuk membenarkan kekeliruan pada ma 'thüf 'alaih. Huruf ini dalam bahasa Indonesia bermakna "tetapi atau bahkan". Contoh: هو ليس معلما بل متعلما/dia bukan seorang guru tetapi murid. Kata متعلما "athaf

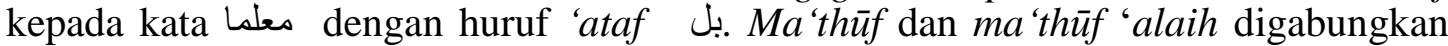
dalam satu hukum yang dikaitkan dengan kata s, namun, ma'thüf merupakan pernyataan susulan sebagai pembenar terhadap kekeliruan penisbatan hukum pada ma'thüf 'alaih.

E. Huruf yang bermakna dan berfungsi untuk menafikan penisbahan hukum terhadap ma'thüf, yaitu: la ( للنفي/لا (27

Huruf ini dalam bahasa Indonesia diterjemahkan "tidak atau belum". Contoh: . نضج البطيخ لا العنب النب

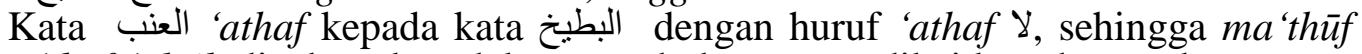

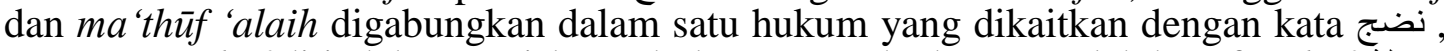
namun, $m a$ 'thüf ditiadakan penisbatan hukumnya terhadap نضج oleh huruf 'athaf $\mathrm{\gamma}$. 
Contoh lain adalah أرحم الرجل الصالح لا الفاسق/saya menyenangi orang shaleh,

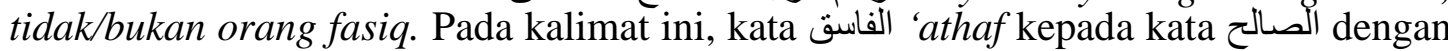
huruf 'athaf $\bar{\vee}$, sehingga $m a$ 'th $\bar{u} f$ dan $m a$ 'th $\bar{u} f$ 'alaih digabungkan dalam satu hukum yang dikaitkan dengan kata أرحم/saya mengasihi. Walau demikian, ma'thüf ditiadakan penisbatan hukumnya terhadap أرحم oleh huruf 'athaf $\mathrm{V}$.

F. Huruf yang Berfungsi membenarkan لكن yang berfungsi dan bermakna membenarkan salah anggapan, yaitu: (لكإستدراك(لكن)

هذا الكتاب صغير :Huruf ini dalam bahasa Indonesia diterjemahkan "tetapi”. Contoh لكن مفيد/buku ini kecil tapi bermanfaat.

Kata مفيد 'athaf kepada kata صغير dengan huruf 'athaf كن Dengan begitu, maka ma'thüf dan ma'thüf 'alaih digabungkan dalam satu hukum yang dikaitkan dengan kata هذا الكتاب. Namun, ma'thüfnya merupakan pembenar terhadap kemungkinan adanya salah duga terhadap ma'thüf 'alaih. Pemahaman itu muncul dengan adanya 'ad̄̄t 'athaf لكن yang digunakan di dalam kalimat tersebut.

\section{Wauw dalam Bahasa Arab}

Huruf waw merupakan huruf ke-24 dalam aksara bahasa Arab. Selain itu, ia juga termasuk huruf $m a$ 'annì yang tidak kurang dari dua belas posisi dalam struktur tata bahasa Arab yang dapat ditempatinya, sepuluh di antaranya adalah:

1. Waw Isti'nāf

Isti'nāf artinya permulaan ${ }^{29}$, karena itu waw ist'nāf adalah huruf waw yang terletak di awal kalimat sempurna secara tersendiri. Fungsi waw isti'năf ini untuk memisahkan kalimat sebelumnya dan kalimat setelahnya ${ }^{30}$, sehingga antara keduanya tidak memiliki keterkaitan. Contoh waw isti'nāf pada ayat Al-Qur'an, salah satunya adalah Q.S. al-'Ankabūt/29:8, sebagai berikut:

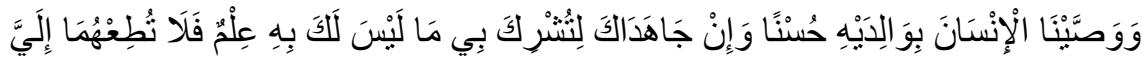

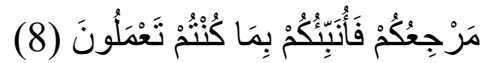

Terjemahnya:

Dan, Kami wajibkan manusia (berbuat) kebaikan kepada dua orang ibubapaknya. Dan, jika keduanya memaksamu untuk mempersekutukan Aku dengan sesuatu yang tidak ada pengetahuanmu tentang itu, maka janganlah kamu mengikuti keduanya. Hanya kepada-Ku-lah kembalimu, lalu aku kabarkan kepadamu apa yang telah kamu kerjakan. ${ }^{31}$

Ayat tersebut di atas tidak memiliki kaitan dengan ayat sebelumnya, sebab huruf waw pada awal ayat hanya merupakan waw isti'nāf.

2. Waw Qasam

Qasam artinya sumpah ${ }^{32}$, sehingga waw qasam berarti huruf waw yang menunjukkan sumpah dan ke dalam bahasa Indonesia diartikan "demi". Untuk fungsi ini, ia terikat dengan $f i$ 'il/kata kerja yang dijatuhkan, yaitu: أقسم bersumpah; dan selalu ada anak kalimat (jawab) yang mengikutinya. Selain itu, waw qasam ini menjar isim yang ada setelahnya. Contoh: الله لأكافئن المجتهر Demi Allah, aku akan memberikan penghargaan kepada orang yang bersungguh-sungguh.

Lafaz الله hukumnya majrūr karena didahului oleh waw qasam, sedangkan

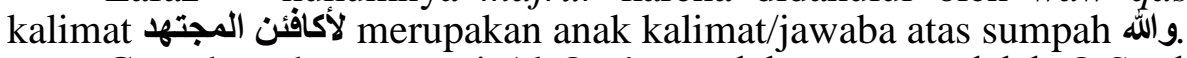

Contoh pada ayat suci Al-Qur'an, salah satunya adalah Q.S. al-‘Asr/103 :1-2., sebagai berikut:

$$
\text { وَالْعَصْرِ (1) إِنَّ الٍِْنْسَانَ لَفِي خُسْرِ (2) }
$$


Terjemahnya:

Demi masa. (1) Sesungguhnya manusia itu benar-benar dalam kerugian, $(2)^{33}$

إنَّ الْإِنْسَانَ لَفِي الْعَصِْ dijar karena didahului waw qasam, sementara kalimat خُسْرِ merupakan anak kalimat (jawaban) dari sumpah.

3. Waw Rubba

Waw Rubba adalah huruf waw tambahan yang terletak di awal kalimat sempurna dan setelahnya terdapat isim/kata benda nakirah yang hukumnya dijar secara lafaz, namun sesungguhnya dirafa' karena ia mubtada' (subyek/pokok kalimat/diterangkan $)^{34}$. Contoh:

$$
\text { وليل كموج البحر أرخى سدوله علي بأنواع الهموم لييتلي }
$$

Terkadang malam seperti ombak di laut;

ia memberikan gerainya begitu lunak bagi-ku

dengan aneka harapan sebagai ujian atas-ku

Kata ليل adalah isim nakirah yang hukumnya dijar oleh waw rubba yang ada sebelumnya. Gabungan waw rubba dan dan isim yang dijar setelahnya adalah mubtada'.

Perbedaan antara waw rubba dan waw qasam dalam menjar isim adalah kalau isim setelah waw rubba adalah nakirah sementara isim yang ada setelah waw qasam adalah ma'rifah.

4. Waw Hāl

$H \bar{a} l$ artinya keadaan ${ }^{35}$, jadi waw hāl adalah huruf waw yang diartikan "dalam kedaan". Dalam tata bahasa Arab, waw häl adalah huruf waw yang posisinya dapat digantikan oleh “إذ"

Contoh: جاء المعلم ووجهه ضاحك Dosen itu datang dalam keadaan tertawa. Huruf

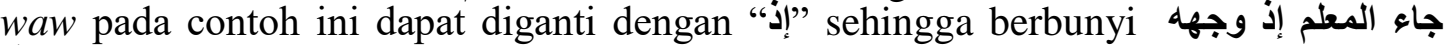
ضاحثك.

5. Waw Ma iyah

Ma iyah berasal dari kata ع/bersama ${ }^{36}$, sehingga waw ma'iyah berarti huruf waw yang diartikan "bersama". Untuk fungsi ini, ia mesti didahului oleh kalimat sempurna, كيف atau ang keduanya merupakan kata tanya (استفهام); dan isim yang ada setelahnya dinasab karena maf'ül ma 'a $a^{37}$, contoh: سرت و شاطئ البحر/aku berjalan menelusuri pinggir pantai.

6. Waw Dhamir

Waw dhamìr atau yang sering juga disebut waw jama'āh adalah huruf waw yang berfungsi sebagai kata ganti bentuk jama'/plural laki-laki. Waw ini hanya mengikut kepada $f i$ ' $l$ kata kerja, baik fi 'il mādhī, mudhāri ' maupun amar.

Contoh: الطلاب يدرسنون/Mahasiswa itu sedang belajar. Huruf waw pada frase يدرسون adalah kata ganti "mereka".

7. Waw 'Alamah al-Raf'i

Karena sebagai tanda rafa', maka waw seperti ini hanya masuk pada isim/kata benda, sebab waw yang masuk pada $f i$ ' $i l / k a t a$ kerja merupakan kata ganti plural lakilaki. Bentuk isim yang dirafa' dengan waw adalah الأ سماء الستة dan جمع المذكر السالم

Contoh: المعلمون قادمون/Para Dosen itu telah datang. Huruf waw pada kata قادمون dadalah sebagai tanda rafa :

Sedangkan contoh ألبوك جالس:Ayahmu sedang duduk. Huruf waw pada kata أبوك adalah tanda rafa،

8. Waw I'tirādh 
I'tirādh secara bahasa artinya keberatan atau protes. ${ }^{38}$ Sementara dalam pengertian istilah tata bahasa Arab, Waw i'tirādh adalah huruf waw yang terdapat di كان محمد - و هو : هوان الرسول الأمين - شجاعا Muhammad -yang merupakan Rasul lagi Jujur itu- adalah

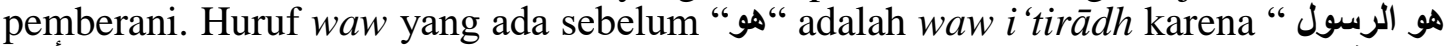

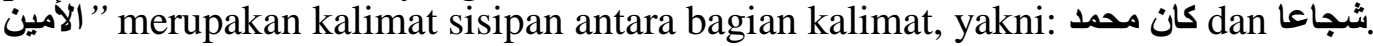

9. Waw Lushūq

Lush $\bar{q}$ secara harfiyah artinya melekat, ${ }^{40}$ sedangkan dalam istilah tata bahasa Arab, Waw lushūq adalah huruf tambahan yang melekat pada kalimat sempurna yang bertujuan mengikat antara dua kalimat yang sebenarnya merupakan $n a$ 'at man' 'üt/ajektiva. Contoh Q.S. al-Baqarah/2:216, sebagai berikut:

Terjemahnya:

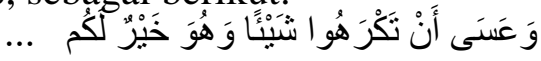

... Boleh jadi kamu membenci sesuatu, padahal ia amat baik bagimu,... ${ }^{41}$

Huruf waw yang ada sebelum هُ adalah waw lushīq yang mengikut kepada kalimat sempurna هُهَ خَبْرِ لَكُم

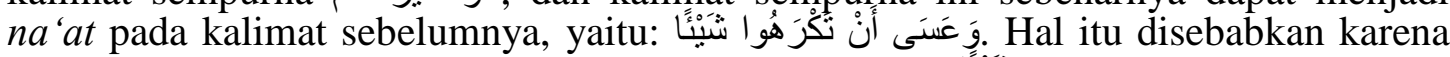
kalimat sempurna setelah nakirah adalah na'at, dan kata

\section{Waw' Athaf}

Selengkapnya waw 'athaf akan dibahas pada pembahasan berikut ini.

\section{E. Waw Athaf dan Penggunaannya dalam Al-Qur'an}

Sebagai huruf 'athaf, waw memiliki beberapa keistimewaan dari harf 'athaf lainnya. Ia disebut sebagai "induknya" huruf "athaf," karena darinya berpangkal pembahasan soal 'athaf, dan ia pula 'adat 'athaf yang paling banyak digunakan.

Muhammad al-Antanākī mengemukakan:

$$
\text { الو او كحرف عطف تعطف مفردا على مفرد أو تعطف جملة على جملة }
$$

Sebagai harf 'athaf, waw menggabungkan kata dengan kata, atau kalimat dengan kalimat.

Definisi ini belum memberikan gambaran yang jelas tentang fungsi khusus waw sebagai huruf 'athaf. Definisi ini baru memberikan gambaran tentang penggunaan waw sebagai huruf 'athaf dalam keteraturan bentuk ma'thüf dan ma'thüf 'alaih. Artinya, bila ma 'thüf nya adalah mufrad maka ma 'thüf 'alaihnya pun mestilah mufrad pula.

Ibnu Mālik menyebutkan mengenai waw sebagai huruf 'athaf dalam bait alfiahnya:

Maka, 'athaf/penggabungan secara mutlak adalah dengan waw...

$$
\text { فالعطف مـطلقا : بواو ....... }
$$

$$
\text { فاعطف بو او لاحقا أو سابقا .... في الحكم أو مصاحبا مو افقا }
$$

Karena itu, 'athafkanlah dengan waw sesuatu yang (terjadi) lebih dahulu atau yang terjadi sesudahnya, atau bersamaan dalam kenyataan.

Huruf waw dipergunakan sebagai alat 'athaf dengan fungsi penggabungan mutlak, yaitu penggabungan pada i'rāb dan nisbah al-hukm. Dalam hal nisbah hukumnya, fungsi ini mencakup tiga kemungkinan ketersusunan waktu, yaitu: 1) antara $m a$ 'th $\bar{f}$ dan $m a$ 'th $\bar{f} f$ 'alaih terjadi secara bersamaan pada waktu yang sama, atau 2) antara keduanya terjadi secara berurutan dan tetap ma'tüf 'alaihnya terjadi lebih dahulu kemudian ma 'thüfnya, atau 3) sebaliknya. Contoh, جاء المهند و العامل al-muhandis wa al-'Ámil,"telah datang insinyur itu dan pekerjanya". Dari segi hukum 
i'rāb, antara al-muhandis dan 'àmil sama, keduanya dirafa' karena fā'il (pelaku/subyek). Kendati demikian, dari segi nisbah hukmnya dalam hal terjadinya perbuatan tersebut terdapat tiga kemungkinan. Yaitu: insinyur dan pekerjanya datang secara bersamaan pada waktu yang sama pula, atau insinyur datang lebih dahulu kemudian pekerjanya, atau sebaliknya.

Hal lain yang bisa dipahami bahwa huruf waw dalam kapasitasnya sebagai alat 'athaf berfungsi menggabungkan antara ma'thüf dan ma'thüf 'alaih sehingga yang terakhir menjadi tergantung pada sebelumnya dalam penisbatan hukum dan $i$ 'rabnya. Pengertian seperti ini dapat dijumpai -salah satunya- pada firman Allah swt. Q.S. al'Ankabūt/29: 15), sebagai berikut:

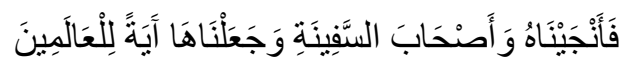

Terjemahnya:

Maka, Kami selamatkan Nuh dan penumpang-penumpang bahtera itu dan

Kami jadikan peristiwa itu pelajaran bagi semua umat manusia. ${ }^{45}$

Penisbahan hukum ma'thüf,"'أصحاب السفينة" sangat tergantung kepada ma 'thüf 'alaih-nya, yaitu kata ganti $/ / h u$,"nya" yang kembali kepada Nuh. Artinya, keselamatan penumpang-penumpang bahtera itu sangat tergantung kepada keselamatan Nuh as.

Juga, waw berfungsi menggabungkan antara ma'thüf dan ma'thüf 'alaih yang berbentuk mufrad ke dalam satu isi berita atau nisbat al-hukm. Contoh sebagaimana di dalam firman Allah swt. Q.S. al-Jumu'ah/62: 2. sebagai berikut :

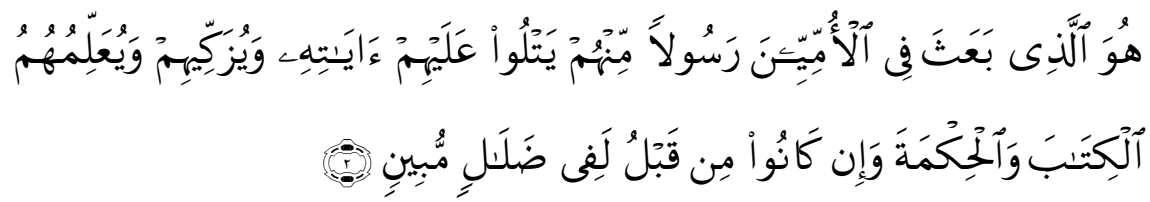

Terjemahnya:

Dia-lah yang mengutus kepada kaum yang buta huruf seorang Rasul di antara mereka, yang membacakan ayat-ayat-Nya kepada mereka, mensucikan mereka dan mengajarkan mereka kitab dan hikmah (As Sunnah). Dan, sesungguhnya mereka sebelumnya benar-benar dalam kesesatan yang nyata, ${ }^{46}$

Kata "الككمة"/al-kitalab"hikmah" pada ayat di atas digabungkan penisbahannya kepada "هو يعلم/huwa yu'allimu", sehingga dipahami bahwa kalimat (ayat) itu mengandung satu isi berita, yaitu: "dia mengajar" al-kitāb dan al-hikmah. Penggabungannya menunjukkan penggabungan mutlak dengan waktu yang bersamaan. Artinya, hukum $i$ 'rāb pada al-kitāb dan al-hikmah sama, yaitu nasab karena maf' $\bar{u} l$ bih (obyek langsung), dan waktu mengajarkan al-kitäb bersamaan dengan waktu mengajarkan al-hikmah. Namun, didahulukannya penyebutan " الكتاب/alkitāb" atas "الحكمة/al-hikmah", karena yang pertama lebih utama dari yang kedua.

Selain itu, waw juga dipergunakan untuk menggabungkan antara ma'thūf dan ma 'thüf 'alaih yang berbentuk kalimat sempurna dalam satu isi berita, nisbat al-hukm, namun tidak pada waktu yang bersamaan antara keduanya, sebagaimana di dalam firman Allah swt. Q.S. al-Syūrā/42: 3. sebagai berikut:

Terjemahnya:

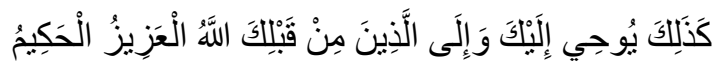

Demikianlah Allah yang Maha Perkasa lagi Maha Bijaksana, mewahyukan kepada kamu dan kepada orang-orang sebelum kamu. ${ }^{47}$ 
“إلى الذين من قبللك،ila al-lażīna min qablikum "kepada (nabi) yang ada sebelum kamu" digabungkan kepada "إلى "kilaik "kepadamu" dalam satu penisbahan, yaitu kepada "هو يوحى". Maksud itu dipahami dari penggunaan 'adat "athaf wauw sebagai penggabung antar keduanya. Artinya, apa yang Dia wahyukan kepadamu, itu juga yang Dia wahyukan kepada (nabi) yang ada sebelum kamu. Namun, kejadiannya tidak berurut sebagaimana waktu realita peristiwanya. Waktu terjadinya "mewahyukan kepada (Nabi) yang ada sebelum kamu" lebih dahulu dari waktu "mewahyukan kepadamu" dengan jarak waktu lama. Berarti, fungsi dan makna waw di sini hanya menggabungkan antara ma'thüf dan ma'thüf 'alaih dalam hal penisbahan isi berita, tidak pada penggabungan waktu yang terjadi secara bersamaan. Waktu terjadinya $m a '$ 'th $\bar{f}$ mendahului waktu terjadinya ma'thüf 'alaih, dengan selang waktu yang cukup lama.

Penggunaan waw sebagai huruf 'athaf dengan fungsi penggabungan mutlak, "tidak diterima oleh kalangan pakar nahw aliran Kūfā. Menurut aliran terakhir ini, waw berfungsi untuk tartīb. ${ }^{48}$ Pendapat mereka didasarkan pada Q.S. alAn'ām/6: 29.

Terjemahnya:

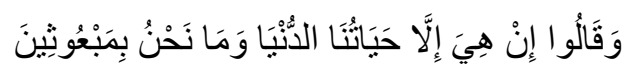

Dan tentu mereka akan mengatakan (pula): "Hidup hanyalah kehidupan

kita di dunia ini saja, dan kita sekali-sekali tidak akan dibangkitkan". ${ }^{49}$

Dari uraian serta pemaparan beberapa contoh di atas, dipahami bahwa penghimpunan dan penggabungan dengan waw 'athaf mengandung tiga kemungkinan. Pertama, penggabungan secara mutlak. Kedua, penggabungan secara berurutan, dan. Ketiga, penggabungan secara tidak berurutan, namun model terakhir ini termasuk jenis paling sedikit.

Penggabungan yang disebutkan pada bagian kedua dan ketiga di atas, juga masih mengandung dua kemungkinan: (a) urutan waktu, dan (b) urutan prioritas. Urutan waktu, menunjukkan berdekatan waktunya, atau memakan selang waktu yang cukup lama; sedangkan urutan prioritas, artinya; mengedepankan yang lebih utama dari yang utama.

Pada penggabungan urutan waktu, waw mengambil makna dan fungsi " "ف/fa" jika tidak berselang waktu lama, dan makna dan fungsi "ث/tsumm" jika berselang waktu agak lama dan atau lama.

Contoh penggabungan secara mutlak dan waktu bersamaan, seperti dalam firman Allah Q.S. al-'Așr/103: 3.

Terjemahnya:

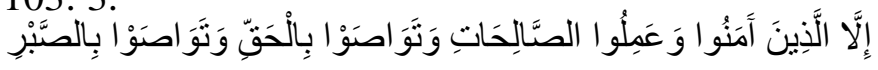

kecuali orang-orang yang beriman dan mengerjakan amal saleh dan nasehat menasehati supaya mentaati kebenaran dan nasehat menasehati supaya menetapi kesabaran. ${ }^{50}$

Iman dan amal şaleh tidak dapat dipisahkan satu dari yang lainnya. Keduanya bagaikan dua sisi mata uang.

Contoh penggabungan berurutan dan berdekatan waktunya, seperti dalam firman Allah Q.S. al-Maidah/5: 6.

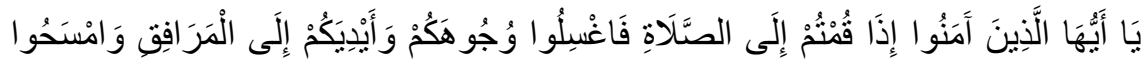

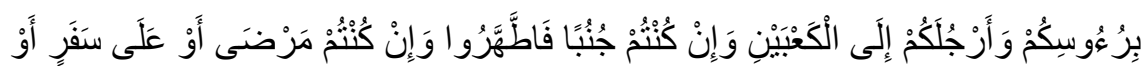

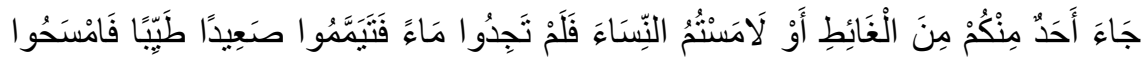




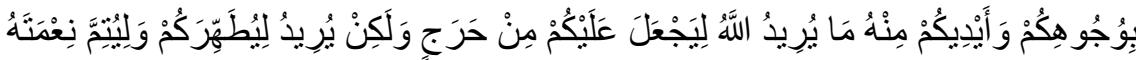

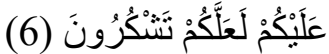

Terjemahnya:

Hai orang-orang yang beriman, apabila kamu hendak mengerjakan shalat, maka basuhlah mukamu dan tanganmu sampai dengan siku, dan sapulah kepalamu dan (basuh) kakimu sampai dengan kedua mata kaki; dan jika kamu junub, maka mandilah; dan jika kamu sakit atau dalam perjalanan atau kembali dari tempat buang air (kakus) atau menyentuh perempuan, lalu kamu tidak memperoleh air, maka bertayammumlah dengan tanah yang baik (bersih); sapulah mukamu dan tanganmu dengan tanah itu. Allah tidak hendak menyulitkan kamu, tetapi Dia hendak membersihkan kamu dan menyempurnakan nikmat-Nya bagimu, supaya kamu bersyukur. ${ }^{51}$

Penggandengan pada ayat tersebut di atas menunjukkan ketersusunan yang berdekatan waktunya. Mayoritas ulama fiqhi bersepakat tentang susunan anggota wudhu sebagaimana yang termaktub dalam ayat tersebut. Pembasuhan muka dan tangan sampai dengan siku, dan penyapuan kepala, serta kaki sampai dengan kedua mata kaki, terjadi tidak berselang waktu lama, karena dilakukan dalam satu rangkaian proses pekerjaan, yaitu wudhu. Maka waw di sini bermakna $f a(\omega)$.

Imām Syāfi'īy (150-205 H) rahimahullāhu berkata,'hendaknya seseorang yang berwudhu memperhatikan dua hal: 1) memulai sebagaimana tuntunan Allah swt. dan Rasul-Nya, 2) menyempurnakan wudhu sebagaimana yang diperintahkan." 52

Orang yang memulai wudhunya dengan membasuh kedua tangan, membasuh kaki lantas dilanjutkan dengan menyapu kepala, maka dia harus mengulangi wudhunya sesuai dengan urutan yang diperintahkan Allah swt. dan Rasul-Nya. Wudhu yang dilakukan tidak sesuai dengan ketentuan (ketersusunan sebagaimana di dalam ayat), hukumnya tidak sah. ${ }^{53}$

Sejalan dengan itu, Syaikh al-Sayyid Sābiq menyebutkan, "diantara farḍu wudhu adalah al-tartīb sebagai yang disebutkan di dalam ayat". Ayat (Q.S. alMaidah/5:6) tersebut menjelaskan wajibnya ketersusunan dalam berwudhu. ${ }^{54}$

Pendapat lebih rinci dikemukakan oleh Wahbah al-Zuhailiy. "Huruf 'athaf, wauw pada ayat tersebut -menurutnya- menunjukkan al-tartīb. "55 Hal itu sejalan pula dengan hadiś Rasūlullāh saw. yang diriwayatkan oleh al-Dārquţnīy melalui sahabat, Jābir, sebagai berikut:

Artinya:

$$
\text { فَابْدَعُو ا بِمَا بَدَاً اللَّهُ بِِهِ (رواه الدارقطنى) }
$$

Mulailah seperti Allah memulainya. ${ }^{57}$

Maksud dari "mulailah sebagaimana Allah memulainya" adalah memulai seperti urutan yang ada pada ayat 6 Q.S. al-Māidah/5. tersebut.

Contoh penggabungan berurutan yang mengandung selang waktu adalah firman Allah swt. Q.S. al-Qaşaş/28: 7.

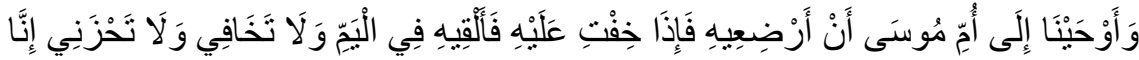

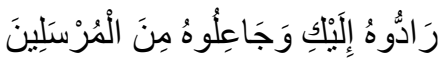

Terjemahnya:

Dan Kami ilhamkan kepada ibu Musa, "Susuilah dia, dan apabila kamu khawatir terhadapnya maka jatuhkanlah dia ke sungai (Nil). 
dan janganlah kamu khawatir dan janganlah (pula) bersedih hati, karena sesungguhnya Kami akan mengembalikannya kepadamu, dan menjadikannya (salah seorang) dari para Rasul. ${ }^{58}$

إنا رادوه dan رادوه Huruf 'athaf waw di sini menggabungkan antara جاعلوه $m a$ 'thüf dan ma'thūf 'alaih berselang lama adalah informasi sejarah (riwayat). Pengembalian Musa kepada ibunya, pada saat ia masih kecil, setelah dihanyutkan ke sungai Nil, sedangkan diutusnya Musa menjadi Rasul, setelah ia berusia 40 tahun. ${ }^{60}$ Karena itu, waw di sini bermakna "ث”"

Contoh penggabungan dengan urutan perioritas adalah firman Allah swt. Q.S. al-Hadīd/57: 26.

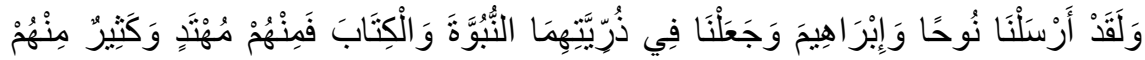

$$
\begin{aligned}
& \text { فَاسبقِونَنَ (26) }
\end{aligned}
$$

Terjemahnya:

Dan, sesungguhnya Kami telah mengutus Nuh dan Ibrahim dan Kami jadikan kepada keturunan keduanya kenabian dan al-Kitab, maka di antara mereka ada yang menerima petunjuk dan banyak di antara mereka fasik. ${ }^{61}$

Penyebutan Nuh mendahului penyebutan Ibrahim karena selain sabagai bapak para Nabi, Nuh juga merupakan Nabi yang diutus lebih dahulu dari Ibrahim.

Demikian juga, Q.S. al-Jumu'ah/62: 2. sebagai berikut :

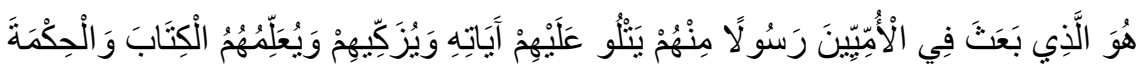

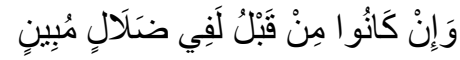

Terjemahnya:

Dia-lah yang mengutus kepada kaum yang buta huruf seorang Rasul di antara mereka, yang membacakan ayat-ayat-Nya kepada mereka, mensucikan mereka dan mengajarkan mereka kitab dan Hikmah (As Sunnah). dan Sesungguhnya mereka sebelumnya benar-benar dalam kesesatan yang nyata, ${ }^{6}$

'Athaf-Ma'thüf yang terdapat pada ayat tersebut di atas menunjukkan ketersusunan urutan waktu dan prioritas. Nuh a.s. lebih awal dari Ibrahim a.s.; dan alkitab lebih utama dari al-hikmah (al-sunnah).

Masih dalam kaitan dengan penggunaannya, waw 'athaf terkadang mengindikasikan kepada pengertian ketidak urutan jenis dan waktu ma'thüf dan $m a ' t h \bar{u} f$ 'alaih. Misalnya, yang disebutkan lebih dahulu (ma'thīf 'alaih) bukanlah berarti mendahului yang lainnya (ma'thüf) dalam jenis dan waktu. Contoh, Q.S. Ali 'Imrān/3: 43.

Terjemahnya:

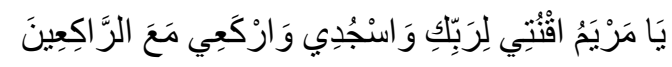

Hai Maryam, taatlah kepada Tuhanmu, sujud dan ruku'lah bersama orang-orang yang ruku'. ${ }^{63}$

Dalam ayat tersebut di atas, terdapat perintah sujud mendahului perintah ruku', padahal runtutan perintah itu adalah rangkaian pelaksanaan shalat. Ini menunjukkan bahwa 'athaf-ma'thüf di situ tidak menunjukkan urutan jenis dan waktu, sebab, kenyataannya rukî -dalam shalat- mendahului sujud.

Contoh lain, Q.S. al-Nisā/4: 163. 


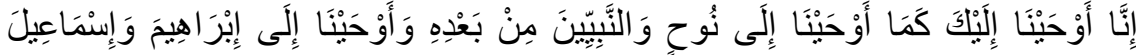

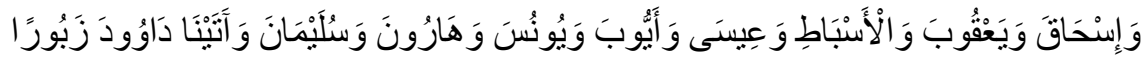

Terjemahnya:

Sesungguhnya Kami telah memberikan wahyu kepadamu sebagaimana Kami telah memberikan wahyu kepada Nuh dan nabi-nabi yang kemudiannya, dan Kami telah memberikan wahyu (pula) kepada Ibrahim, Isma'il, Ishak, Ya'qub dan anak cucunya, Isa, Ayyub, Yunus, Harun dan Sulaiman. dan Kami berikan Zabur kepada Daud. ${ }^{64}$

Penyebutan urutan Nabi dalam konteks ayat di atas tidak menunjukkan perurutan jenis dan waktu. Nabi Isa a.s. disebutkan sebelum Nabi Ayub, Yunus, Harun, dan Sulaiman 'alaihim al-saläm, sementara, menurut informasi riwayat tidak demikian halnya. Nabi Isa hidup sesudah masa Nabi Ayyub dab Yunus álaihima alsalām.

Penyebutan demikian terdapat pula pada Q.S. al-A'rāf/7: 122.

Terjemahnya:

$$
\text { رَبِّْ مُوسَى وَهَارُونَ }
$$

"(yaitu) Tuhan Musa dan Harun". ${ }^{65}$

Di sini, Musa a.s. disebutkan sebelum Harun a.s. sementara pada Q.S. T $\square$ āha/20: 70., Harun disebutkan sebelum Musa a.s. Allah swt. berfirman:

Terjemahnya:

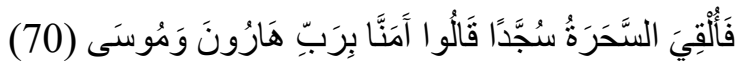

Lalu tukang-tukang sihir itu tersungkur dengan bersujud, seraya berkata: "Kami telah percaya kepada Tuhan Harun dan Musa". ${ }^{6}$

Ini menunjukkan antara ' $m a$ 'th $\bar{f}$-ma' thüf' alaih tidak berurutan waktunya.

Demikian waw dalam penggunaannya sebagai alat 'athaf. Kecuali itu, ia juga memiliki keistimewaan dibandingkan dengan huruf 'athaf lainnya. Keistimewaan itu adalah, sebagai berikut:

1. Bisa bergandengan dengan "إِl", 67 contoh pada Q.S. al-Insān/76: 3., sebagai berikut.

Terjemahnya:

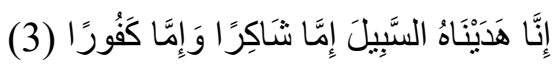

Sesungguhnya Kami telah menunjukinya jalan yang lurus; ada yang bersyukur dan ada pula yang kafir. ${ }^{68}$

2. Bisa bergandengan dengan " $\gamma$ " jika tidak didahului oleh nafy, peniadaan dan tidak bermakna ma 'iyyah, bersama. ${ }^{69}$ Contoh, ما قام زياد و لا سليم wa lā Salìm "Ziad tidaklah berdiri dan tidak juga Salim. Demikian juga pada firman Allah swt. pada Q.S. Sabā/34: 37., sebagai berikut:

Terjemahnya:

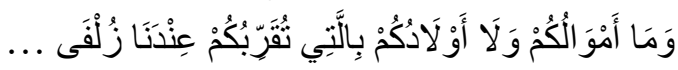

Dan, sekali-kali bukanlah harta dan bukan (pula) anak-anak kamu yang mendekatkan kamu kepada Kami sedikitpun ... ${ }^{70}$

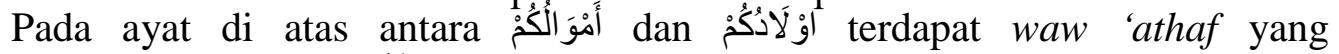
bergandengan dengan $\gamma$. 
3. Bisa bergandengan dengan " "كن" 71 , contoh sebagaimana pada'Q.S. alAhzāb/33: 40., sebagai berikut:

Terjemahnya:

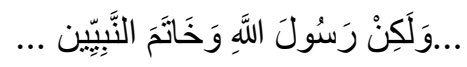

... tetapi, dia adalah Rasulullah dan penutup nabi-nabi. ... ${ }^{72}$

4. Bisa dipakai meng-'athaf-kan kata kepada kata lain yang tidak terkait dengan isi kalimat. Contoh, زيد جألس عمرو و غلامه/Zaid jālisun 'Amr wa gulāmuhu "Zaid dan Amr duduk, demikian juga putranya".

Maksudnya, غلامه di 'athafkan kepada عمرو, sمرو) tidak masuk dalam bagian kalimat, karena ia hanya 'athaf kepada زيرو/Zaid. Ia bukan subyek diterangkan, dan bukan pula predikat menerangkan.

5. Dipakai mengikat bilangan puluhan, contoh:

6. Bisa dipakai meng-'athaf-kan dua kata yang sama dengan maksud dual, ${ }^{73}$ contoh:

$$
\text { أقمنا بها يوماو يوما و ثالثا و ويوما له يوم الترحل خامس }
$$

Kata يوما pada bagian pertama bait syair itu terulang dua kali. Pengulangan kata bentuk tunggal yang sama seperti itu dapat didualkan menjadi يومان/yaumān "dua hari". Namun, disini di 'athafkan antara keduanya.

7. Meng- 'athaf-kan dua kata yang saling terkait, ${ }^{74}$ contoh:

$$
\text { اختصم علي و باقر }
$$

Antara ma'thüf dan ma'thüf 'alaih saling terkait sehingga keduanya tidak bisa dipisahkan. Keterkaitannya disebabkan arti yang tercakup pada kata اختصم/ikhtașama "berbantah". "berbantah" tidak mungkin dilakukan oleh satu orang saja. Karena itu, ma'thüf mesti ada, dan saling terkait dengan ma'thüf 'alaihnya.

8. Meng-'athaf-kan yang khusus kepada yang umum, dan atau sebaliknya ${ }^{75}$. Contoh pada Q.S. Nūḥ/71: 28., sebagai berikut:

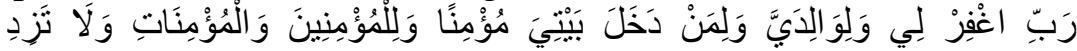

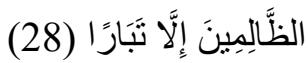

Terjemahnya:

Ya Tuhanku! ampunilah aku, ibu bapakku, orang yang masuk ke rumahkuu dengan beriman dan semua orang yang beriman laki-laki dan perempuan. dan janganlah Engkau tambahkan bagi orang-orang yang zalim itu selain kebinasaan". ${ }^{76}$

"ampunilah aku" lebih khusus dari "ibu bapakku" dan "orang-orang yang beriman yang masuk ke dalam rumahku". "aku" hanya satu orang, karena itu ia lebih khusus, sementara "ibu bapakku" lebih dari satu orang, dan demikian juga "orang-orang yang beriman yang masuk ke dalam rumahku". Maka, penggandengan pada ayat tersebut dimulai dari yang khusus ke yang umum dan lebih umum.

Contoh 'athaf yang khusus kepada yang umum, Q.S. al-Aḥzāb/33: 7., sebagai berikut:

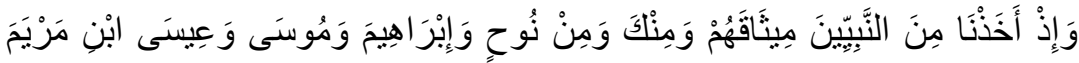

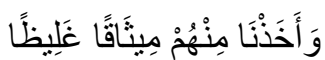

Terjemahnya: 
Dan, (ingatlah) ketika Kami mengambil perjanjian dari Nabi-nabi dan dari kamu (sendiri) dari Nuh, Ibrahim, Musa dan Isa putra Maryam, dan Kami telah mengambil dari mereka perjanjian yang teguh. ${ }^{77}$

"dari nabi-nabi" lebih umum dari "kamu", Nuh, Ibrahim, Musa dan Isa putra Maryam. Keumuman "dari nabi-nabi" karena cakupannya lebih dari satu orang, sementara gandengannya setelah itu hanya menunjukkan satu orang. Karena itu, penggabungan di sini dimulai dari yang umum kepada yang khusus.

9. Meng-'athaf-kan kata kepada sinonimnya ${ }^{78}$, contoh pada firman Allah swt., Q.S. al-Baqarah/2: 157., yakni:

Terjemahnya:

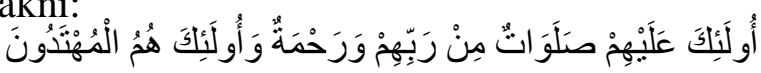

Mereka itulah yang mendapat keberkatan yang sempurna dan rahmat dari Tuhan mereka dan mereka itulah orang-orang yang mendapat petunjuk. ${ }^{79}$

“صلوات/berkat yang sempurna” digabungkan kepada " "رحمة/rahmat", dan antara kedua kata itu adalah sinonim. Maka, penggabungan pada ayat ini antara dua kata yang sinonim.

10. Kemungkinan ma 'thīfnya untuk arti "bersama" dan "berurut". 80

Terjemahnya:

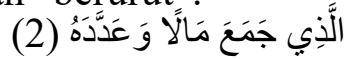

Yang mengumpulkan harta dan menghitung-hitung. ${ }^{81}$

Ma'tūf pada di atas adalah عَدَّدَهُ /'addadah/menghitung-hitung, sementara ma'tūf 'alaihnya adalah Penggabungan antara keduanya menunjukkan arti bersama dan atau berurut. Yakni, waktu mengumpulkan harta bersama dan atau berurutan dengan waktu menghitung-hitungnya.

\section{F. Penutup}

Setelah meneliti wauw 'aţaf, fungsi, makna, dan keistemewaannya dari huruf 'aţaf lainnya, maka di akhir tulisan ini penulis mengambil beberapa kesimpulan, sebagai berikut:

1. Fungsi dan makna wauw sebagai alat 'athaf Pertama, sebagai penggabungan murni seperti pada Q.S. al-An'ām/6: 151., dan kedua, penggabungan secara berurutan seperti pada Q.S. Yusūf/12: 99.

Penggabungan yang disebutkan pada bagian kedua di atas masih mengandung dua kemungkinan: [a] urutan waktu seperti pada Q.S. Yusūf/12: 99., dan [b] urutan prioritas Q.S. Luqmān/31:14. Urutan waktu, artinya berdekatan waktunya atau memakan selang waktu yang cukup lama. Peroses penyambutan Yūsuf terhadap ayahnya beserta saudara-saudaranya membutuhkan selang waktu, maka di sini waw bermakna śumma/kemudian, sementara antara peristiwa masuknya ayah Yūsuf, Ya'qūb a.s. dan dirangkulnya oleh Yūsuf terjadi secara berurutan tanpa ada jarak waktu, maka di sini waw bermakna fa/lalu.

2. Interpretasi linguistik dalam menafsirkan ayat-ayat Al-Qur'an demikian sangat penting, karena dengan itu berbagai pesan Ilāhī dapat diungkap. Penelusuran makna dan fungsi waw 'athaf pada ayat-ayat al-Qur'an 
sangat diharapkan agar diadakan kajian-kajian tafsir kebahasaan lanjutan untuk mengenal lebih dalam lagi makna dan fungsi waw athaf dan atau huruf ma‘āni lainnya.

End Notes:

${ }^{1}$ M. Qraish Shiahab, Tafsir al-Misbah,Pesan, Kesan dan Keserasian Al-Qur'an Vol 1,(Jakarta: Lentera Hati, Cet X, 2007), h. V.

${ }^{2}$ QS. al-Qiyāmah/75: 17-19.

${ }^{3}$ Departemen Agama, Al-Qur'an dan Terjemahnya., Jilid 4, h. 495.

${ }^{4}$ Ibid., Jilid 9, h. 567.

${ }^{5}$ Muhammad Mahmud Hijazy, Al-Tafsìr al-Wādih, juz XXVII (Mesir: Al-Istiqlāl alKubrā, 1973), h. 38 .

${ }^{6}$ Lihat Jalāl al-Dīn al-Suyūthiy, al-Itqān fì 'Ulūm al-Qur'ān, juz I (Mesir: al-Bāby alHalab wa Awlāduh, 1981), h. 180.

${ }^{7}$ Ibrahim Anis., et al., Al-Mu'jam al-Wasīt $\square$, Tahqīq Majma' al-Lugah al-'Arabiyah Jilid II (Cairo: Maktabah al-Syurūq al-Dawliyah, 1425 H/2004 M), h. 123.

${ }^{8}$ Musa bin Muhammad bin al-Milyānīy al-Aḥmadīy, Mu'jam al-Af'āl al-Muta 'ddiyah bi Harf (Beirut: 'Ilm li al-Malāyīn, 1986), h. 241.

9 Al-Syaikh Mușafā al-Galāyainīy, Jāmi' al-Durūs al-'Arabiyah, Jili I (Beirut: al-'Așriyah, t.th), 242 .

${ }^{10}$ Ibid., h. 243.

${ }^{11}$ Qāḍīy al-Quḍāh Bahāuddīn 'Abd Allāh bin 'Uqayl al-'Uqayliīy, Syarh ibn 'Aqūl,. Jilid II (Beirut: Dār al-Fikr, 1414 H/1994 M), h.191.

${ }^{12}$ Ibid.

${ }^{13}$ Departemen Agama, op.cit,. Jilid 6, h. 604.

${ }^{14}$ Al-Gulāyainī̄y, op.cit,. h. 245.

${ }^{15}$ Imād Hātim, al-Lugah al- 'Arabiyah; Qawā'id al-Nuṣuṣs (Cairo: Mansyā al-Sya'biyah li alNasyr wa al-Tauzi', 1979), h. 153.

${ }^{16}$ Ibnu ‘Aqīl, Syarh li Ibni Aqil,. Jilid II, h. 197.

${ }^{17}$ Departemen Agama, op.cit,. Jilid 7, h. 581

${ }^{18}$ Fuād Ni'mah, loc.cit.

${ }^{19}$ Departeman Agama, op.cit,. Jilid 10, h. 800.

${ }^{20}$ Fuād Ni'mah, loc.cit. 
${ }^{21}$ Aḥmad Jamīl Syāmīy, Mu'jam Hurūf al-Ma'ānīy (Beirut: Muassasah 'Iz al-Dīn, 1413 H/1992 M), h. 41-43.

${ }^{22}$ Fuād Ni’mah, loc.cit,.

${ }^{23}$ Rāmīl, op.cit,. h.276.

${ }^{24}$ Jamīl Syāmīy, op.cit,. h. 123.

${ }^{25}$ Departemen Agama, op.cit,. Jilid 7 h. 147.

${ }^{26}$ Fuād Ni'mah, loc.cit.

${ }^{27}$ Fuād Ni'mah, loc.cit,

${ }^{28}$ Fuād Ni'mah, loc.cit.

${ }^{29}$ Ibrāhīm Anis, et al. op.cit., Jilid I, h. 63.

${ }^{30}$ Rāmīl Badī' Ya'qūb, Mausū'ah al-Nahwi wa al-Sarfi wa al-I'rāb (Beirut: Dār al-'Ilmi li alMalāyīn, 1986), h. 570.

${ }^{31}$ Departemen Agama, op.cit., Jilid 7, h. 364

${ }^{32}$ Ibrāhīm Anis, et al. op.cit., Jilid II, h. 385.

${ }^{33}$ Departemen Agama, op.cit., Jilid, h. .

${ }^{34}$ Rāmīl Badī‘ Ya’qūb, op.cit., h. 569.

${ }^{35}$ Ibrahin Anis, et-Majma‘ al-Lugah al-'Arabiyah, op.cit, Jilid I, h. 434.

${ }^{36}$ Ibrāhīm Anis, et al., op.cit, Jilid II, h. 673.

${ }^{37}$ Ahmad Jamīl Syāmī, Mu 'jam Hurūf al-Ma'ānī (Beirut: Muassasah 'Iz al-Dīn, 1413 H/1992 M), h. 82 .

${ }^{38}$ Ibrāhīm Anis et al., op.cit, Jilid II, h. 567.

${ }^{39}$ Rāmīl Badī' Ya 'qūb, op.cit. h, 571.

${ }^{40}$ Majma' al-Lugah al-'Arabiyah, op.cit, h.

${ }^{41}$ Departemen Agama, op.cit., jilid 1, h. 216

42 Abū al-Hasan 'Ālī bin Ismāīl Ibn Sayyidih, Al-Mukhașșaș, Juz III (Beirut: Dār al-Kutub al'Ilmiyah, t.th), h. 217.

${ }^{43}$ Muhammad al-Antanāky, Minhāj fi al-Qawā'id wa al-'Irāb, (Beirut: Maktab Dār al-Syirq. [tt]), hal.34.

${ }^{44}$ Ibnu 'Aqīl, op.cit,. h, 197.

${ }^{45}$ Ibid., Jilid 7, h. 374.

${ }^{46}$ Ibid., Jilid 10, h. 126.

${ }^{47}$ Ibid., Jilid 9, h. 19.

${ }^{48}$ Ibnu 'Aqīl, op.cit., h. 199. 
${ }^{49}$ Ibid., Jilid 3, h. 213.

${ }^{50}$ Ibid., Jilid 10, h. 766.

${ }^{51}$ Ibid., Jilid 2, h. 360.

52 Syaikh Ahmad Mușţafā al-Farrān, Tafsīr al- Imām al-Syāfi '̌̄y, Jilid II (Riyāaḍ: Dār alTadmūriyyah, 2006), h. 307.

${ }^{53}$ Ibid.

${ }^{54}$ Al-Syaikh Sayyid Sābiq, Fiqh al-Sunnah. Mujallad I (Beirūt: Dār al-Fikr, 1303 H/1983 M), h. 39.

55 Wahbah Zuhaylīy, al-Tafsīr al-Munīr fì al-'Aqīdah wa al-Syarī'ah wa al-Manhaj, jilid III (Damsyiq: Dār al-Fikr, Cet. VIII, 1326 H/2005 M), h. 457.

56، Ālī bin’ Umar al-Dāruquţn̄y, Sunan al-Dāruquţn̄yy Juz I, (Beirūt:Muassasah al-Risālah, 1424 H/2004 M), h, 371.

57 Bandingkan dengan 'Abd Allāh bin Muhammad 'Abd al-Raḥmān bin Ishāq āl-Syaikh, Lubāb al-Tafsīr min Tafsīr Ibn Kaśīr (Cairo: Muassasah Dār al-Hilāl, 1414 H/1994 M), h, 37-38.

${ }^{58}$ Departemen Agama, op.cit,. Jilid 7, h. 268.

${ }^{59}$ Muhammad Muhy al-Dīn al-Darwīsy, I'rāb Al-Qur'an al-Karīm wa Bayānuh (Beirūt: Dār Ibn Kaśīr,1424 H/2003 M), h. 574.

${ }^{60}$ Syekh Jamāl al-Dīn bin Hisyām al-Anşarī, Mugni al-Labīb 'an Kutub al-A'ārib, juz IV (Mesir: Dār Iḥyā Kutub al-‘Arabiyah. [t.th].) h.353.

${ }^{61}$ Departemen Agama, op.cit,. Jilid 10 h. 127.

${ }^{62}$ Ibid., Jilid 10, h. 450.

${ }^{63}$ Ibid., Jilid , h. 495.

${ }^{64}$ Ibid., Jilid, h.

65 Ibid., Jilid , h.

${ }^{66}$ Ibid., Jilid 5, h. 187.

${ }^{67}$ Ibnu Hisyām, op.cit., h. 355.

${ }^{68}$ Departemen Agama, op.cit., Jilid 10, h. 463.

${ }^{69}$ Ibnu Hisyām, op.cit., 356.

${ }^{70}$ Departemen Agama, op.cit., Jilid 10, h. 463.

${ }^{71}$ Ahmad Jamīil, op.cit,. h. 87.

${ }^{72}$ Departemen Agama, op.cit., Jilid 8, h. 11.

${ }^{73}$ Ibnu Hisyām, op.cit., h. 357.

${ }^{74}$ Ibid.

${ }^{75}$ Ahmad Jamīil, op.cit,. h. 87. 
${ }^{76}$ Departemen Agama, op.cit., Jilid 10, h. 372.

${ }^{77}$ Ibid., Jilid 7, h. 620.

${ }^{78}$ Ahmad Jamīil, op.cit,. h. 88.

${ }^{79}$ Departemen Agama, op.cit., Jilid 1, h. 231.

${ }^{80}$ Ahmad Jamīil, op.cit,. h. 88.

${ }^{81}$ Departemen Agama, op.cit., Jilid 10, h. 231.

\section{DAFTAR PUSTAKA}

Aḥmad Jamīl Syāmīy, Mu’jam Hurūf al-Ma'ānīy Beirut: Muassasah 'Iz al-Dīn, 1413 H/1992 M.

Abū al-Hasan 'Ālī bin Ismāīl Ibn Sayyidih, Al-Mukhașșaș, Juz III Beirut: Dār alKutub al-'Ilmiyah, t.th.

'Ālī bin' Umar al-Dāruquţnīy, Sunan al-Dāruquţīy Juz I, Beirūt:Muassasah alRisālah, 1424 H/2004 M.

'Abd Allāh bin Muḥammad 'Abd al-Raḥmān bin Ishāq āl-Syaikh, Lubāb al-Tafsīr min Tafsìr Ibn Kaśīr Cairo: Muassasah Dār al-Hilāl, 1414 H/1994 M.

Departemen Agama, Al-Qur'an dan Terjemahnya., Jilid 4.

Ibrahim Anis., et al., Al-Mu'jam al-Wasīth, Tahqīq Majma' al-Lugah al'Arabiyah Jilid II Cairo: Maktabah al-Syurūq al-Dawliyah, 1425 H/2004 M.

Imād Hātim, al-Lugah al- 'Arabiyah; Qawā'id al-Nuṣūṣ Cairo: Mansyā al-Sya'biyah li al-Nasyr wa al-Tauzi', 1979.

Jalāl al-Dīn al-Suyūthiy, al-Itqān fì 'Ulūm al-Qur'ān, juz I Mesir: al-Bāby alHalab wa Awlāduh, 1981.

Muhammad Mahmud Hijazy, Al-Tafsīr al-Wāḍh, juz XXVII Mesir: Al-Istiqlāl al-Kubrā, 1973.

M. Qraish Shiahab, Tafsir al-Misbah, Pesan, Kesan, dan Keserasian Al-Qur'an Vol 1, Jakarta: Lentera Hati, Cet X, 2007.

Musa bin Muhammad bin al-Milyānīy al-Aḥmadīy, Mu'jam al-Af'āl al-Muta 'ddiyah bi Harf Beirut: 'Ilm li al-Malāyīn, $198 \dot{6}$.

Muhammad al-Antanāky, Minhāj fi al-Qawā'id wa al-'Irāb, Beirut: Maktab Dār alSyirq. [tt].

Muhammad Muhy al-Dīn al-Darwīsy, I'rāb Al-Qur'an al-Karīm wa Bayānuh Beirūt: Dār Ibn Kaśīr,1424 H/2003 M. 
Qāḍīy al-Quḍāh Bahāuddīn 'Abd Allāh bin 'Uqayl al-'Uqaylī̄y, Syarh ibn 'Aqūl,. Jilid II Beirut: Dār al-Fikr, 1414 H/1994 M.

Rāmīl Badī' Ya'qūb, Mausū 'ah al-Nahwi wa al-Sarfi wa al-I'rāb Beirut: Dār al-'Ilmi li al-Malāyīn, 1986.

Syaikh Ahmad Mușţafā al-Farrān, Tafsīr al-Imām al-Syāfi '̄oy, Jilid II Riyāaḍ: Dār alTadmūriyyah, 2006.

Al-Syaikh Sayyid Sābiq, Fiqh al-Sunnah. Mujallad I Beirūt: Dār al-Fikr, 1303 H/1983 M.

Al-Syaikh Musţafā al-Galāyainīy, Jāmi' al-Durūs al-'Arabiyah, Jili I Beirut: al'Așriyah, t.th.

Syekh Jamāl al-Dīn bin Hisyām al-Anşarī, Mugni al-Labīb 'an Kutub al-A'ārib, juz IV Mesir: Dār Ihyyā Kutub al-'Arabiyah. [t.th]..

Wahbah al-Zuhaily, Ushūl al-Fiqh al-Islāmi, juz II t.tp: Dār al-Fikr, t.th.

Wahbah Zuhaylīy, al-Tafsīr al-Munīr fì al-'Aqīdah wa al-Syarī'ah wa al-Manhaj, jilid III Damsyiq: Dār al-Fikr, Cet. VIII, 1326 H/2005 M. 